International Journal of Economics, Business and Accounting Research (IJEBAR)

Peer Reviewed - International Journal

Vol-4, Issue-2, 2020 (IJEBAR)

E-ISSN: 2614-1280 P-ISSN 2622-4771

https://jurnal.stie-aas.ac.id/index.php/IJEBAR

\title{
THE INFLUENCE OF PERSONALITY AND ORGANIZATIONAL COMMITMENT AND WORK ENGAGEMENT TO EMPLOYEE SATISFACTION AND EMPLOYEE PERFORMANCE DPRD SAMARINDA CITY
}

\author{
Fuad Fakhruddin1) Zainal Ilmi2) Gusti Noorlitaria Achmad3) \\ 1,2,3Faculty of Economics and Business Mulawarman University \\ Email:fakhruddinfuad94@gmail.com1),zainal.ilmi@feb.unmul.ac.id2), \\ gusti.noorlitaria.achmad@feb.unmul.ac.id33)
}

\begin{abstract}
In this study involving Civil Servants in Samarinda City DPRD. In this study, to see the performance of employees used a sample of 82 respondents. The data analysis used by the author is the Structural Equation Model (SEM). Hypothesis testing is done by multivariate analysis carried out through the SmartPLS program. Data analysis through partial Least Square (PLS) is done through two stages, namely: First, Assessing the outer model or measurement model. Second, assess the inner model or structural model. The results showed that Personality had a positive influence on employee job satisfaction, organizational commitment had a positive influence on employee job satisfaction, work engagement gave a positive effect on satisfaction, Personality had a positive influence on employee performance, organizational commitment had a positive influence on employee performance, work engagement provide a positive influence on employee performance, job satisfaction has a positive influence on the performance of employees of the Samarinda City Regional Representative Council. Keywords: Personality, Organizational Commitment, Work Engagement, Job Satisfaction, Employee Performance
\end{abstract}

Keywords: Personality, Organizational Commitment, Work Engagement, Satisfaction, Performance

\section{Introduction}

The problem that occurs in Samarinda City DPRD is that employees lack commitment to the organization, this occurs because the organization has not been able to provide the needs of employees as assets of the organization, which in reality is employees helping in achieving organizational goals. Organizations have not been able to instill organizational beliefs and values to employees and employees feel that they have no economic value if they remain in the organization. In addition to organizational commitment another thing that can affect performance is employee personality, many previous studies have examined that there is a positive relationship between personality and performance.

Personality is a dynamic arrangement that is hidden within a person which is a system that will create a characteristic arrangement of behavior, thoughts, and feelings of a person. Personality represents the characteristics of a person that is noted for the constant arrangement of feelings, thoughts and behavior. Personality is a very broad definition that will focus into many aspects of a person's differences. At the same time personality suggests that we follow a fixed set of behaviors and qualities that are hidden from someone. 
The personalities of Samarinda City DPRD employees do not yet represent the personality desired by the organization because employees are no longer oriented towards achieving organizational goals but employees are oriented towards achieving personal goals. This can be improved if the organization is able to provide employee needs in accordance with its proportions.

Performance can arise from various factors in the organization, including because of job satisfaction from employees and high organizational commitment (Robbin, 2007). When employees feel satisfaction with the work done, then the employee will work optimally in completing his work, even doing some things that might be outside his duties. Likewise, when someone has a high commitment to the organization, then that person will do anything to advance the organization because of their belief in the organization (Luthans, 2006). When someone gets job satisfaction and has a high commitment to the organization, employees will provide good service and vice versa, when employees do not experience satisfaction then the services provided to consumers, in this case students and lecturers can be unsatisfactory. Job satisfaction is defined as a person's emotional response to aspects in or on the whole work. The emotional state or attitude of a person will be shown in the form of responsibility, attention, and development of performance.

\section{Theoretical Review}

\section{Relationship Between Variables Personality with job satisfaction}

Personality is a dynamic arrangement that is hidden within a person which is a system that will create a characteristic arrangement of a person's behavior, thoughts, and feelings (Garver \& Michael, 2008). Personality is also interpreted as a combination of a balance of physical and mental characteristics that give a person's identity (Kreitner \& Angelo, 2001). Personality is a unique and dynamic psychophysical entity that contains habits and attitudes that are very useful in dealing with and adjusting the demands of one's life and life (Hadjam, 1997). Basically the more positive the work attitude the greater the job satisfaction, for that various indicators of job satisfaction need to get special attention so that workers can improve their performance, including motivation, culture, leadership and stress (Lunenberg \& Orsntein, 2005). In general, a person feels satisfied with his work because he is successful and gets a fair assessment from his leader (Suharsaputra, 2009). Because motivation is so important for every individual, an organization must be able to create motivation for its employees. Heller (1998) motivation is the desire or drive to act.

\section{Organizational commitment with job satisfaction}

Every member of the organization has the same opportunity, for example for promotion, the basis used for promotion is the ability, skills, interests, job satisfaction, performance without any discrimination. Thus satisfaction has an important relationship with organizational commitment, job satisfaction is one aspect of the process of organizational commitment. In the organizational psychology literature, organizational commitment and job satisfaction usually develop independently to some extent. Meyer (2008: 89) says that commitment is one of the important components of job satisfaction, Meyer believes that commitment is considered as an important part of job satisfaction.

Previous experts have stated in their research that if someone feels that all their needs and desires have been fulfilled by the organization, then automatically they will increase their level of commitment automatically, according to the opinions of Luthan (1995) and Ganzach (1998) which states that positive variables on job satisfaction are the type of work itself, incentives or pay, opportunities for promotion, their supervisors and coworkers can be fulfilled so commitment to the organization will arise 
International Journal of Economics, Business and Accounting Research (IJEBAR)

Peer Reviewed - International Journal

Vol-4, Issue-2, 2020 (IJEBAR)

E-ISSN: 2614-1280 P-ISSN 2622-4771

https://jurnal.stie-aas.ac.id/index.php/IJEBAR

properly, so satisfaction will impact on organizational commitment. But there is also other empirical evidence showing the unclear relationship between job satisfaction with organizational commitment where research conducted between the two variables shows inconsistent results William (1986) \& Mathieu (1988).

Other researchers have found a relationship between organizational commitment and job satisfaction showing inconsistent results for example as stated by Mathieu (1988), Price \& Mueller (1986) they stated that job satisfaction is a variable that precedes organizational commitment and vice versa Organizational commitment has preceded satisfaction work according to the opinion of Bateman \& Strasser (1984) so that research that examines the relationship of job satisfaction levels in increasing organizational commitment is an interesting topic and has many uses, to reconcile conflicting findings, Ferris (1981) states that the nature of organizational commitment can change all the time.

\section{Work engagement with job satisfaction}

Work attachments form relationships about how well people feel compatible with their work and community; how the relationship between people in work and outside work; and what they will give up or sacrifice if they leave their position or community. Work engagement is a network that encourages individuals to remain in the organization, where the network is divided into the organization itself and the community within it. Kismono (2011) argues that employees who have work attachments in their work will feel more attached to colleagues, work and organization and express their attachment by maintaining organizational membership in the place where they work. Individuals who feel there is a strong bond (embedded) between themselves with work and their organizations tend to have positive behavior in achieving organizational goals compared to individuals who feel less there is a bond between themselves and the organization that can cause satisfaction in their work (Firtiyani, 2013).

\section{Personality with Performance}

Personality is also a good predictor for measuring employee performance in situations where management's expectation that employees display the performance is clearly defined, in addition to the characteristics of the Indonesian people who uphold the value of togetherness and help (Purba \& Seniati, 2004) and Indonesia's ranking high in the dimension of collectivism (Purba \& Seniati, 2004) then the Indonesian people should display high performance. Moorman \& Blakely (2004) states that individuals who have high collectivistic values tend to cause high performance. One personality theory that is used as a personality approach that has a standalone personality dimension is the Big Five Personality (Kumar, at al. 2009). The Big Five Personality Factor or personality factors according to Costa \& McCrae (Pervin, Cervone \& John, 2005), namely the basic personality traits of interrelated individuals arranged with five main characteristics that are broad in them, such as extraversion, neuroticism, opennes to experience, agreeableness, and conscientiousness.

\section{Organizational Commitment with Performance}

Organizational commitment is identification (trust in organizational values), involvement (willingness to do their best for the sake of the organization) and loyalty (the desire to remain a member of the organization concerned) expressed by an employee of the organization. Furthermore Steers stated that organizational commitment is a condition where employees are very interested in the goals, values and goals of the organization. Commitment to the organization means more than formal membership, because it includes an attitude of liking the organization and a willingness to strive for a high level of effort for the interests of the organization for the achievement of objectives. Organizational commitment has an important role in shaping the character of the organization, through organizational commitment employees will have competitiveness as measured by performance. Robbins (2007: 89) found the effect of organizational commitment on performance, commitment is seen as a value orientation towards organizations that shows individuals are very concerned about and prioritize their work and organization. Individuals will try to give all their business in order to help the organization 
International Journal of Economics, Business and Accounting Research (IJEBAR)

Peer Reviewed - International Journal

Vol-4, Issue-2, 2020 (IJEBAR)

E-ISSN: 2614-1280 P-ISSN 2622-4771

https://jurnal.stie-aas.ac.id/index.php/IJEBAR

achieve its goals.

\section{Work engagement with performance}

Shafique et al. (2011), who conducted research focusing on the performance and behavior of the organization of lecturers with higher education in Pakistan, found that work attachment had a positive effect on performance. Kismono (2011) who examined the relationship between work attachment in organizations and behavior towards the organization and the influence of sex in these variables found that work engagement has a positive influence on behavior toward the organization. Omar et al. (2012), which focused on examining behavioral phenomena towards organizations in nurses who work permanently at public hospitals in Peninsular, Malaysia, found that job embeddnednes on performance through job satisfaction significantly affected performance.

\section{Job satisfaction with performance}

Performance can arise from various factors in the organization, including because of job satisfaction from employees and high organizational commitment (Robbin \& Judge, 2007). When employees feel satisfaction with the work done, then the employee will work optimally in completing his work, even doing some things that might be outside his duties. Likewise, when someone has a high commitment to the organization, then that person will do anything to advance the organization because of their belief in the organization (Luthans, 1995). When someone gets job satisfaction and has a high commitment to the organization, employees will provide good service and vice versa, when employees do not experience satisfaction then the services provided to consumers, in this case students and lecturers can be unsatisfactory. Job satisfaction is defined as a person's emotional response to aspects in or on the whole work (Nawawi, 1998). The emotional state or attitude of a person will be shown in the form of responsibility, attention, and development of performance.

\section{Hypothesis}

Taking into account the background of the problem, the theoretical study of previous research, the relationship between variables and the conceptual framework, the following hypotheses are proposed:

1) Personality has a positive and significant effect on employee job satisfaction.

2) Organizational commitment has a positive and significant effect on employee job satisfaction.

3) Work engagement has a positive and significant effect on employee job satisfaction.

4) Personality has a positive and significant effect on employee performance.

5) Organizational commitment has a positive and significant effect on employee performance.

6) Work engagement has a positive and significant effect on employee performance.

7) Job satisfaction has a positive and significant effect on employee performance.

\section{Research Methods}

\section{Population and Sample}

In this study involving all Civil Servants in the working environment of Samarinda City DPRD totaling 82 respondents. Sugiyono (2013: 81) explains that the sample is part of the number and characteristics possessed by the population. The sampling technique in this study is nonprobability sampling. The greater the number of samples, the better, the sample of this study is Samarinda City DPRD employees, using the census method. Based on the explanation above, it can be seen the number of samples in this study were 82 respondents.

In this study, the data analysis method that will be used is the Stability Analysis Equation Modeling (SEM). This analysis method is used to analyze the pattern of relationships between variables. In this study data analysis uses the Partial Least Square (PLS) approach. PLS is a Structural Equation Modeling (SEM) equation model based on components or variants. Ghozali (2008: 18), PLS is an alternative approach that shifted from the covariant-based SEM approach to variant-based. Covariance-based SEM generally tests causality / theory while PLS is more 
International Journal of Economics, Business and Accounting Research (IJEBAR)

Peer Reviewed - International Journal

Vol-4, Issue-2, 2020 (IJEBAR)

E-ISSN: 2614-1280 P-ISSN 2622-4771

https://jurnal.stie-aas.ac.id/index.php/IJEBAR

predictive model. PLS is a powerful analysis method (Ghozali, 2008: 18), because it is not based on many assumptions, for example: data must be normally distributed, samples do not have to be large. Besides being able to be used to confirm theories, PLS can also be used to explain the presence or absence of relationships between latent variables. PLS can simultaneously analyze constructs that are formed with reflective and formative indicator Ghozali (2008: 19) PLS's goal is to help researchers for predictive purposes. The formal model defines latent variables as linear aggregates of the indicators. Weight estimates for creating a component score of latent variables are based on how the inner model (the structural model that links between latent variables) and the outer model (the measurement model that is the relationship between indicators and constructs) is specified. The result is the residual variance of the dependent variable. Parameter estimates obtained with PLS can be categorized into three. First, the weight estimate is used to create a latent variable score. Second, reflecting the path estimate (path estimate) that connects latent variables and between latent variables and their indicators (loading). Third, related to the means and location parameters (regression constant values) for indicators and latent variables (Ghozali, 2008: 19).

\section{4. $\quad$ Result}

\section{Research Analysis}

Based on the loading factor values for each indicator of several variables in order to obtain a new research model with the following pictures:

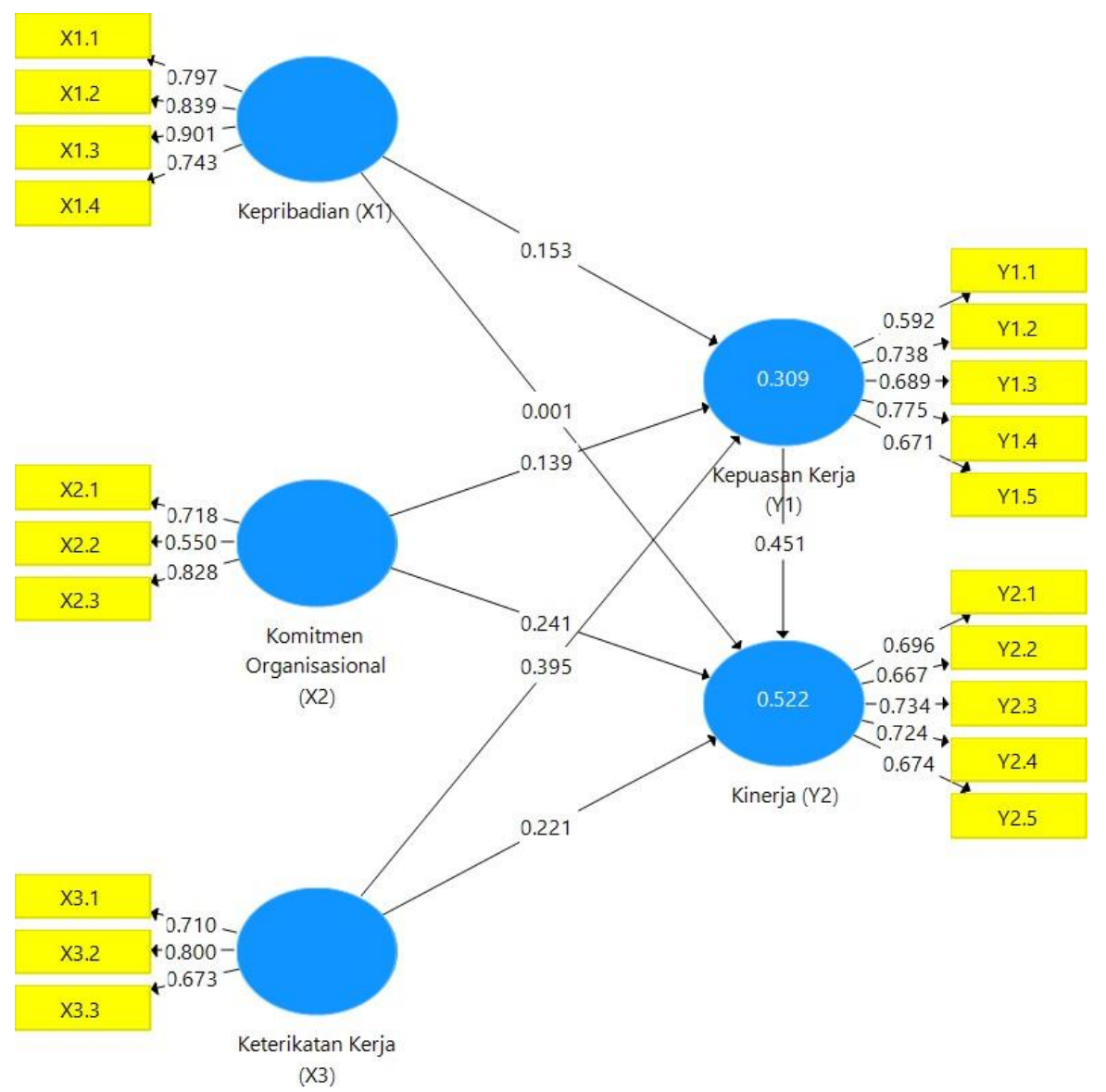

Picture:

New Research Model 
International Journal of Economics, Business and Accounting Research (IJEBAR)

Peer Reviewed - International Journal

Vol-4, Issue-2, 2020 (IJEBAR)

E-ISSN: 2614-1280 P-ISSN 2622-4771

https://jurnal.stie-aas.ac.id/index.php/IJEBAR

Based on the picture above it appears that all loading factors are 0.50 so the research can proceed to analyze the measurement model or outer model and structural model or inner model.

\section{Model Struktural atau Inner Model \\ Goodness of Fit Model}

Examination of the model can be seen from the value of R2 (R-square). This means that the model can explain the phenomenon or satisfaction variation can be explained by Personality, organizational commitment and work engagement variables of 30.90 percent $(0.309 \times 100 \%)$ while the rest is explained by variations of other variables outside of the research model by $69.10(100 \%-30,90 \%)$.

The phenomenon or variation in performance can be explained by Personality, organizational commitment and work engagement as well as satisfaction by 52.20 percent $(0.522 \times 100 \%)$ while the rest is explained by variations of other variables outside of the research model by $47.80(100 \%-52.50 \%)$, with the table explanation below:

Table: $\mathbf{R}$-square

\begin{tabular}{|c|c|}
\hline & $\mathrm{R}$-square \\
\hline Personality & \\
\hline Organizational commitment & \\
\hline Work engagement & 0.309 \\
\hline Satisfaction & 0.522 \\
\hline Performance & \\
\hline
\end{tabular}

Source: Output SmartPLS

\section{T-test testing}

The smartPLS program is done by t-test on each track. The test results can be seen in the table below:

Table: Results For Inner Weights

\begin{tabular}{|l|r|r|r|}
\hline & $\begin{array}{l}\text { Original } \\
\text { Sample }\end{array}$ & \multicolumn{1}{l|}{$\begin{array}{l}\text { S } \\
\text { Statistics }\end{array}$} & P Values \\
\hline Personality $\rightarrow$ Satisfaction & 0.153 & 1.284 & $\mathbf{0 . 2 0 0}$ \\
\hline $\begin{array}{l}\text { Organizational commitment } \longrightarrow \\
\text { Satisfaction }\end{array}$ & 0.139 & 1.262 & $\mathbf{0 . 2 0 8}$ \\
\hline Work engagement $\longrightarrow$ Satisfaction & 0.395 & 3.541 & $\mathbf{0 . 0 0 0}$ \\
\hline Personality $\longrightarrow$ Performance & 0.001 & 0.008 & $\mathbf{0 . 9 9 3}$ \\
\hline $\begin{array}{l}\text { Organizational commitment } \rightarrow \\
\text { Performance }\end{array}$ & 0.241 & 2.432 & $\mathbf{0 . 0 1 5}$ \\
\hline Workengagement $\longrightarrow$ Performance & 0.221 & 1.967 & $\mathbf{0 . 0 5 0}$ \\
\hline Satisfaction $\longrightarrow$ Performance & 0.451 & 4.137 & $\mathbf{0 . 0 0 0}$ \\
\hline
\end{tabular}

Source: Output SmartPLS

Based on the Table, it can be seen the positive influence and the level of significance of each variable, if T-Statistic> 1.96 means that exogenous variables have a significant influence on endogenous variables and if $\mathrm{T}$ - Statistic <1.96, exogenous variables give insignificant influence on endogenous variables with an explanation as following:

1) Effect of Personality on satisfaction; Personality has a positive influence on employee satisfaction, it can also be seen that Personality does not have a significant effect on employee satisfaction in Samarinda City DPRD. 
International Journal of Economics, Business and Accounting Research (IJEBAR)

Peer Reviewed - International Journal

Vol-4, Issue-2, 2020 (IJEBAR)

E-ISSN: 2614-1280 P-ISSN 2622-4771

https://jurnal.stie-aas.ac.id/index.php/IJEBAR

2) The effect of organizational commitment on satisfaction; organizational commitment gives a positive influence on employee satisfaction, it can also be seen that organizational commitment does not have a significant effect on employee satisfaction in Samarinda City DPRD.

3) The effect of work engagement on satisfaction; work engagement gives a positive influence on employee satisfaction, it can also be seen that work engagement gives a significant effect on employee satisfaction in Samarinda City DPRD.

4) Effect of Personality on performance; Personality has a positive influence on employee performance, it can also be seen that Personality has no significant effect on the performance of Samarinda City DPRD Employees.

5) The effect of organizational commitment on performance; organizational commitment gives a positive influence on employee performance, it can also be seen that organizational commitment has a significant effect on the performance of Samarinda City DPRD Employees.

6) The effect of work engagement on performance; work engagement gives a positive influence on employee performance, it can also be seen that work engagement has a significant effect on the performance of Samarinda City DPRD Employees.

7) Effect of satisfaction on performance; satisfaction gives a positive influence on employee performance, it can also be seen that satisfaction gives a significant effect on the performance of Samarinda City DPRD Employees.

\section{Conclusions and Suggestions}

Associated with the relationship between variables in the model, based on the results of the analysis presented in the previous chapter conclusions can be drawn as follows:

1) Personality has a positive and insignificant influence on the satisfaction of Samarinda City DPRD employees, meaning that the better the personality, the satisfaction will increase, but the effect is not significant.

2) Organizational commitment gives a positive and insignificant influence on the satisfaction of Samarinda City DPRD employees, meaning that the better the organizational commitment, the satisfaction will increase, but the effect is not significant.

3) Work engagement gives a positive and significant influence on employee satisfaction in Samarinda City DPRD, meaning that the better the work engagement, the satisfaction will increase and the effect will be meaningful.

4) Personality has a positive and not significant effect on the performance of Samarinda City DPRD employees, meaning that the better the personality, the performance will increase, but the effect is not significant.

5) Organizational commitment gives a positive and significant influence on the performance of Samarinda City DPRD employees, meaning that the better organizational commitment, the performance will increase and the effect will be meaningful.

6) Work engagement gives a positive and significant effect on the performance of Samarinda City DPRD employees, meaning that the better the work engagement, the performance will increase and the effect will be meaningful.

7) Satisfaction has a positive influence on the performance of Samarinda City DPRD employees, meaning that the better the satisfaction, the performance will increase and the effect will be meaningful.

\section{Suggestion}

Suggestions that can be given from the results of this study are as follows:

1) Personality needs to be considered and developed by Samarinda City DPRD Employees so that they can play a role in their performance. This will not arise by itself without any 
International Journal of Economics, Business and Accounting Research (IJEBAR)

Peer Reviewed - International Journal

Vol-4, Issue-2, 2020 (IJEBAR)

E-ISSN: 2614-1280 P-ISSN 2622-4771

https://jurnal.stie-aas.ac.id/index.php/IJEBAR

stimulation from outside oneself. Increased personality for Samarinda City DPRD Employees will generate the expected performance. Thus, it can be ascertained that to achieve the high performance of Samarinda City DPRD Employees, personality cannot be separated from performance, because these factors are supporting in arousing the enthusiasm and enthusiasm of Samarinda City DPRD Employees in completing the work they face.

2) Organizational commitment is a variable that affects the performance of Samarinda City DPRD Employees, so that work can be improved so that the human resources they have can increase in accordance with the high enthusiasm in Samarinda City DPRD Employees.

3) To increase satisfaction, the policy of Samarinda City DPRD Employees needs to pay attention to the division of labor in accordance with capabilities. Performance can be improved in addition to reducing pressure on Samarinda City DPRD Employees and improving welfare can also be done with opportunities to attend education and skills.

4) So that satisfaction can improve employee performance needs to be considered: aligning employees with their work through effective selection, testing and placement procedures, correctly orienting employees to work and providing the necessary work engagement, giving positive and constructive feedback to employees about performance and condition employees to be able to express their problems to management.

5) It is recommended to conduct more in-depth research on the factors that influence satisfaction and performance not only limited to Personality, organizational commitment and work engagement, so that it can be thoroughly known what variables influence employee satisfaction and performance because it is based on the $\mathrm{R}$ test -square value of free influence on the dependent variable is still in a small percentage.

6) Future research is expected to include the variables of supervision, education, compensation, employee work ability, leadership and communication as well as other variables that are considered to be reliable with employee satisfaction and performance as variables that can affect the satisfaction and performance of Samarinda City DPRD Employees.

\section{References}

Armstrong, Michael, 2010, Human Resource Management, Pentonvillroad, London.

As'ad, Mohamad, 2008, Human Resources, Edition IV, Liberty, Yogyakarta.

Bateman, T and S, Strasser, 2008, A Longitudinal analysis of antecedents of the antecedent of organizational commitment, Academy of Management Journal 27: 95-112.

Daft, Richard L, 2002, Management, Fifth Edition Volume One, Erlangga, Jakarta.

Darmawati, Hidayati, Herlina. 2013. The influence of organizational satisfaction and commitment to the study performance of the employees of the Faculty of Social Sciences and Economics Yogyakarta State University.

Davis, Keith and Newstorm, John W, 2008, Organizational Behavior: Human Behavior at work, Mc-Graw Hill Companies, New York.

Dharma, Agus 2004, Management Supervision, Revised Edition, PT, Raja Grafindo Persada, Jakarta.

Desiana, P.M \& Sotipto, B.W, 2006, The Influence of Role Stressor and Perceived Organizational Support on Work Decision and Commitment:

Case Study Assistant Lecturer of FEUI, Entrepreneur No. 05 of XXXV

Dessler, Gary, 2010, Human Resources Management, Eight Edition, Prentice Hall, New Jersey.

Fitriyani, Windri. 2013. The Effect of Personality and Job Embeddedness on Organizational Citizenship Behavior (OCB) on the Employees of PT. Hadji Kalla Makassar. Journal of the Faculty of Economics \& Business, Hasanuddin University. p: 17.

Gibson et al., L, James, Donelly Jr. H, James and Ivansevich M, John, 2001, Fundamental of Management, Eight, Richard D, Irwin Inc., New York.

Gitosudarmo \& Sudita, 2010, Organizational Behavior of the First Edition, Erlangga, Jogjakarta. Gomes, Faustino Cardoso, 2010, Human Resources Management, Andi Offset Publisher, 
International Journal of Economics, Business and Accounting Research (IJEBAR)

Peer Reviewed - International Journal

Vol-4, Issue-2, 2020 (IJEBAR)

E-ISSN: 2614-1280 P-ISSN 2622-4771

https://jurnal.stie-aas.ac.id/index.php/IJEBAR

Yogyakarta.

Handoko, T, Hani, 2006, Management of Personnel and Human Resources, Second Edition, BPFE UGM, Yogyakarta.

Kismono, Nervous. 2011. The Relationships Between Job Embeddedness, Work-Family Conflict, and the Impact of Gender on Turnover Intention: Evidence from the Indonesian Banking Industry. Thesis of Piloshopy: pp: 1-10.

Kuntjoro, Zainuddin Sri. 2002. Organizational Commitment. Jakarta. http://www.epsikologi.com/problem/250702.htm

Kumar, K. J., Bakhshi. A \& Rani. E. 2009. Linking the Big Five Personality Domains to Organizational Citizenship Behavior. International Journal of Psychological Studies. 1 (2), 73-81.

Kouzes, J, M, \& Posner, B, Z, 2007, The Leadership Challenge, 4th Eds, John Wiley and Sons, New York.

Levinson. 2010. Human Resources System and Sustained Competitive Advantage: A Competency Based Perspective, Academy of Management Review, 19

Llyod, Byer, and Lislie W, Rue 2009, Management Skills and Apply Applications, Richard D, Irwin, Illinois, USA.

Luthans, Fred, 2006, Organizational Behavior (Interpreting V, A Yuwono, et al), Indonesian Edition, ANDI, Yogyakarta.

Maholtra, 2004, Research Methods, New Edition, Rineka Cipta, Jakarta.

Mathis, Robert L, and John H, Jackson, 2009, Human Resource Management, Issue 10, Salemba Empat, Jakarta.

Mathieu, J, 2010, A Cross Level Nonrecursive Model of The Antecendent of Organizational Commitment and Satisfaction, Journal of Applied Psychology 76 (5): 607-618.

Martoyo, Susilo, 2008, Human Resource Management, BPFE, Yogyakarta.

Muhammad, Arni, 2004, Organizational Communication, PT Bumi Aksara, Jakarta.

Nugraheni 2007, Relationship between Job Embeddedness and Performance for PT Bank Danamon Jakarta employees

Omar, Khatijah, Abdul Halim Abdul Majid and Husna Johari. 2012. Job Satisfaction and Turnover Intention Among Nurses: the Mediating Role of Moral Obligation. 3rd 2782 International Conference on Business and Economic Research (3rd ICBER 2012) Proceeding, p: 1 .

Pervin, L.A, Cervone, D \& John, O.P. 2005. Personality theory and research. John Wiley \& Sons, Inc.

Prawirosentono. 2012. Leadership and Organizational Behavior, First edition, PT Raja Grafindo, Jakarta.

Price J, E and Mueller, C, 2010, A Causal Model Turnover for Nurses, Academy Management Journal, 24 (3): 88-109.

Priyatno, Dwi, 2009, Mandiri Learning SPSS, MediaKom, Yogyakarta.

Purba, D. E \& Seniati, A. N. C. 2004. The influence of personality and organizational commitment on organizational citizenship behavior. Makara, Social Humanities, 8 (3), 105-111.

Purwanto, Djoko, 2003, Business Communication, Erlangga Jakarta Second Edition.

Pace, Wayne and Faules, Don F, 2006, Organizational Communication, PT Remaja Rosdakarya, Bandung.

Rahmi. 2013. The effect of transformational leadership on performance and organizational commitment with mediation satisfaction (study on Permanent Teachers of Public High Schools in East Lombok District)

Rangkuty, Fredy, 2005, Marketing Research, Third Printing, PT Publisher, Gramedia Pustaka Umum, Jakarta.

Rivai, Veithzal, 2005, Leadership and Organizational Behavior, First edition, PT Raja Grafindo, 
International Journal of Economics, Business and Accounting Research (IJEBAR)

Peer Reviewed - International Journal

Vol-4, Issue-2, 2020 (IJEBAR)

E-ISSN: 2614-1280 P-ISSN 2622-4771

https://jurnal.stie-aas.ac.id/index.php/IJEBAR

Jakarta.

Robbins, Stephen P, 2007, Organizational Behavior, Tenth Edition, Prentice Hall, Upper Saddle River, New Jersey.

Saefullah, Kurniawan and Ernie Tisnawati Sule. 2006. Introduction to Management. First edition. Jakarta. Prenada Media.

Sedarmayanti, 2001, Human Resources and Productivity, CV, Mandar Maju, Bandung.

Shafique, Muhammad., Faisal Qadeer, Munir Ahmad, Rashid Rehman. 2011. Impact of Job Embeddedness on Leave Intention: Understanding From Higher Education (HE) System. African Journal of Business Management, 5 (30): p: 1.

Sule, Ernie Tisnawati. 2002. Introduction to Management. First edition. Jakarta.

Sugiyono, 2013, Combined Research Methods (Mixed Methods, Alfabeta, Bandung.

Sunyoto, Danang, 2012, Path Analysis Model for Economic Research, Yrama Widya, Bandung.

Terry, George R, 2009, Principle Of Management, Richard D, Irwin, Inc. Homewood, Illinois Irwin Dorsey Limited, Illinois, USA.

Tohardi, Ahmad, 2004, Practical Understanding of Human Resource Management, First Printing, Mandar Maju, Bandung.

Umar, Husein, 2009, Research in Human Resources in Organizations, PT Gramedia Pustaka Utama, Bandung.

Usmara 2006. New Paradigm in Human Resource Management.Yogyakarta: Amara Books

Wow, Bagja. 2007. Sociology: Diving Social Phenomena in the Community.

Bandung: PT Setia Purna Inves.

Widyasari, Ratna, Suci Paramitasari Syahlani and Krhisna Agung Santosa. 2007. Effect of Personality on the Performance of Higher Educated Employees: Analysis of Animal Husbandry Companies in Central Java and Yogyakarta Special Areas. (Online) vol. 11, No.1

Wijayanto. 2004, Effect of Job Embeddedness on Performance mediated by a sense of responsibility

William, 2006, "An examination of professional commitments in public accounting", Accounting, Organization and Society 6: PP, 271-228.

Wursanto I, G, 2002, Staffing Management Volume 1, Kanisiu, Yogyakarta.

Yoder, Dale. 2007. Human Resource Management. Erlangga Bandung. 